\title{
Proximate and sensory properties of African breadfruit and sweet potato-wheat composite flour in cakes and biscuits
}

\author{
Eke-Ejiofor, J. \\ Department of Food Science and Technology, Rivers State University of Science and Technology, Nkpolu, P.M.B 5080, Port Harcourt
}

Email address:

joyekee@yahoo.co.uk

\section{To cite this article:}

Eke-Ejiofor, J.. Proximate and Sensory Properties of African Breadfruit and Sweet Potato-Wheat Composite Flour in Cakes and Biscuits. International Journal of Nutrition and Food Sciences. Vol. 2, No. 5, 2013, pp. 232-236. doi: 10.11648/j.ijnfs.20130205.13

\begin{abstract}
The study assessed the quality of biscuit and cake produced from African breadfruit and sweet potato-wheat composite flour. Four blends of breadfruit, sweet potato/wheat were prepared in the proportions: 20:80, 30:70, 40:60, and $50: 50 \%$ and wheat used as control. Flour blends were used to bake cake and biscuit. Proximate, physical properties and sensory attributes of the cakes and biscuits were examined. Results of proximate analysis showed that moisture content of biscuit ranged from 3.00- 6.79, fat 21.93 - 27.37, protein 5.5 - 7.08, carbohydrate 57.68 - 65.24 while moisture content in cake ranged from 21.97- 22.26, fat 18.93 and showed a total dislike for the taste, aroma, texture and color/appearance of any of the samples. All qualities evaluated did not significantly $(\mathrm{p} \leq 0.05)$ affect the acceptability and preference of the samples. Wheat flour could be substituted with African breadfruit and sweet potato flour up to $20 \%$ level in cake making and $30 \%$ in biscuit improved nutritional and sensory properties.
\end{abstract}

Keywords: African Breadfruit, Sweet Potato, Cake, Biscuit, Proximate, Sensory

\section{Introduction}

African breadfruit (Treculia africana) is a traditionally important edible fruit tree used in Nigeria (Okafor, 1985) whose importance is due to the potential use of it seeds, leaves, timber, roots and bark. It is increasingly becoming commercially important in Southern Nigeria hence, Baiyeri and Mbah (2006) described it as an important natural resource which contributes significantly to the income and dietary intake of the poor. The seeds have an excellent polyvalent dietetic value whose biological value exceeds even that of soybeans (WAC, 2004) and are used for cooking. They are highly nutritious and constitute a cheap source of vitamins, minerals, proteins, carbohydrates and fats (Okafor and Okolo, 1974). It can thus be used as substitute for rice, yam and other starchy foods (Enibe, 2007). Apart from being consumed as main dish, the seeds are also processed into flour which has high potential usage for pastries (Keay, 1989).

The Sweet potato (Ipomoea batatas) is an economical and healthful food crop containing beta-carotene and substantial amounts of ascorbic acid and minerals (Woolfe, 1992). Potatoes are the seventh most important food crop in the world. Sweet potato has a large potential to be used as a food in developing nations with limited resources because of its short maturity time and ability to grow under diverse climatic condition and on less fertile soil. Options for sweet potato products are numerous and based on recent diagnostic assessments carried out in developing countries; dried chips, starch and flour were identified among the most promising (Collins, 1989). Sweet potato flour can serve as a source of energy and nutrients and can add natural sweetness, color, flavor and dietary fiber to processed food products (Woolfe, 1992; Ulm, 1988)

Cake is a form of bread or bread-like food, typically a sweet baked dessert (Okaka, 2005). Cakes normally contain flour, sugar, eggs, butter or oil with some varieties also requiring liquid (typically milk or water) and leavening agents such as yeast or baking powder (Bakingandbakingscience.com). Cakes have enjoyed a relatively constant place in our diet for a long time and its continuous popularity has encouraged the development of newer and more attractive products that are available in the market today. It is often a dessert of choice for meals at ceremonial occasions, particularly wedding anniversaries and birthdays (Eke et al., 2008).

Biscuits are nutritive snacks produced from unpalatable 
dough that is transformed in appetizing product through the application of heat in an oven (Kure et al., 1998). They are ready-to-eat convenient and inexpensive food product containing digestive and dietary properties of vital importance (Kulkarni, 1997). The principal ingredients are flour, fat, sugar and water; while other ingredients include milk, salt, flouring agent and aerating agent (Wade, 1988). Biscuits are a rich source of fat and carbohydrate, hence are energy giving food and they are also a good source of protein and minerals (Kure et al., 1998).

Increasing urbanization in African countries is changing the food habit and preferences of the population towards convenience foods. Consumption of biscuits and similar foods made from wheat has become so popular in Nigeria that its total elimination from the dietary pattern could have nutritional and socio economic implications. Unfortunately, wheat cannot be grown in Nigeria leaving sourcing to importation paid with scarce foreign currency. The ban on importation of wheat into the country has contributed immensely to the present high cost of bakery and confectionery products. Partial or complete substitution of wheat flour with flours from tropical crops such as roots, tubers and underutilized seeds like African breadfruit could tremendously reduce importation of wheat (Morton, 1988 and Satin, 1988).This study therefore aims at the production and evaluation of cakes and biscuits from wheat/African breadfruit/sweet potato composite flour.

\section{Materials and Methods}

\subsection{Materials}

The African breadfruit (Treculia africana) and Sweet potato (Ipomoea batatas) used for this study were purchased from mile one market in Diobu, Port Harcourt. The wheat flour was a commercial baker's grade milled by flourmills Nigeria Limited, Port Harcourt. Other ingredients such as sugar, margarine, fresh eggs, salt, sodium bicarbonate (baking powder) were also purchased from mile one market in Diobu, Port Harcourt, Rivers State.

\subsection{Chemicals}

All the chemicals and equipments used in this analysis were of analytical grade and were obtained from the biochemistry laboratory of the Department of Food Science and Technology. Rivers State University of Science and Technology.

\subsection{Sample Preparation}

\subsubsection{African Breadfruit}

The African breadfruits were thoroughly washed to remove dirt and unwanted materials. They were then peeled and washed with clean water, then dried on aluminum foil in a GallenKamp hotbox oven at $70^{\circ} \mathrm{c}$ for 18 hours. Dried African breadfruit seeds were milled into flour (Giami, et al 2004). Flour obtained was sieved through a $60 \mathrm{~mm}$ mesh size to obtain flour of uniform particle size. It was stored in an airtight container and used for baking and subsequent analysis

\subsubsection{Sweet Potato Flour}

The fresh sweet potatoes (Ipomoea batatas) were thoroughly washed to remove dirt and soil. They were peeled, washed, blanched with $0.25 \%$ of sodium metabisulphite solution for $15 \mathrm{mins}$, cut into slices and dried in a Gallenkamp hotbox oven at $70^{\circ} \mathrm{c}$ for 18 hours. Dried sweet potato chips were milled into flour (Eke and Kabari, 2010). Flour obtained was sieved through a $60 \mathrm{~mm}$ mesh sieve to obtain flour of uniform particle size. The flour was then packed in an air tight container for future use.

\subsubsection{Blend Ratio}

Five blends were prepared by mixing African breadfruit flour and sweet potato flour respectively with wheat. Flour was in the following percentage proportions of $0,20,30,40$, 50 for baking biscuit and cake.

Table 1: Composition of Wheat/ Sweet potato/African breadfruit flour for Cake Production.

\begin{tabular}{llllll}
\hline Samples & $\begin{array}{l}\text { Substitution } \\
\text { level (\%) }\end{array}$ & WF & SF/BF & $\begin{array}{l}\text { Sugar } \\
\text { for } \\
\text { cake }\end{array}$ & $\begin{array}{l}\text { Sugar } \\
\text { for } \\
\text { biscuit }\end{array}$ \\
\hline A & 100 & 100 & 0 & 125 & 100 \\
B & 80 & 80 & 10 & 125 & 100 \\
C & 70 & 70 & 15 & 125 & 100 \\
D & 60 & & & & 125 \\
E & 50 & 60 & 20 & 125 & 100 \\
\hline
\end{tabular}

\subsection{Chemical Analysis of Cake \& Biscuit}

Proximate analysis of the samples was carried out using the AOAC method (1990) for moisture, ash, crude fat, protein and fiber. Total carbohydrate was calculated by difference.

\subsubsection{Sensory Evaluation}

Cake and biscuit samples were subjected to sensory evaluation within 24 hours after production. The following attributes namely, taste, aroma, texture, appearance and overall acceptability were assessed on cake and biscuit samples using a 9-point hedonic scale with 9 as like extremely and 1 as dislike extremely (Ihekoronye and Ngoddy, 1985). Twenty panelists familiar with cake and biscuit, who were neither sick nor allergic to baked products were involved in the assessment. The panelists were instructed to rinse their mouth with water after tasting each cake and biscuit samples respectively.

\subsubsection{Statistical Analysis}

Results were analyzed statically using Analysis of Variance (ANOVA) and means were separated by Least 
Significant Difference (LSD) procedure (Ihekoronye and Ngoddy 1985)

\section{Results and Discussion}

Table 2 and 3 show the proximate composition of wheat/sweet potato and African breadfruit cakes and biscuits made from five different blends. Moisture content ranged from $3.00-6.79 \%$ in biscuit and $21.97-22.26 \%$ in cake with Samples E and D having the least and highest in biscuit and Samples B and E in cake respectively, showing an increase and decrease in moisture content as substitution increased. Fat content ranged from $21.93 \%-27.37 \%$ in biscuit and $18.93 \%-21.79 \%$ in cake. Protein content ranged from 5.59\% - 7.08\% in biscuit and 5.78\% - 7.34\% in cake with sample A as the lowest and Sample E as the highest. Fat and protein content in biscuit and cake showed an increase with increase in substitution. Fiber ranged from $1.00 \%-2.40 \%$ in biscuit and $0.01 \%-1.82 \%$ in cake. Carbohydrate ranged from $65.24 \%-57.68 \%$ in biscuit and $47.76 \%-48.72 \%$. Ash ranged from $2.25 \%-2.12 \%$ in cake and $1.05 \%-1.17 \%$ in biscuit showing increase in some level of substitution and decrease in others. The carbohydrate contents were highest for biscuits and cakes in terms of all proximate composition parameters as determined in this study. This was expected as the ingredients composed of mainly carbohydrate rich ingredients such as wheat, African breadfruit and sweet potato flours.

Table 4 and 5 show the sensory evaluation result of the Wheat/African breadfruit and Sweet potato cake and biscuit. Appearance/color by physical examination ranged from $1.1 \%$ - $7.5 \%$ for biscuit and $6.20 \%-7.50 \%$ for cake while taste score ranged from $6.3 \%-6.9 \%$ in biscuit and $6.30 \%-8.00 \%$ in cake with sample D having the lowest score for biscuit and sample B having the highest score. Aroma values ranged from $5.9 \%-6.6 \%$ in biscuit and $6.65 \%-8.05 \%$ in cake with sample D having the lowest score in biscuit and $\mathrm{B}$ the highest score. General acceptability values ranged from $1.1 \%-7.0 \%$ in biscuit and $6.05 \%-8.05 \%$ in cake with sample $\mathrm{C}$ and $\mathrm{B}$ as the most preferred in biscuit and cake.

Table 2: Proximate composition of African breadfruit and sweet potato/ Wheat biscuit.

\begin{tabular}{|c|c|c|c|c|c|c|}
\hline Samples & $\begin{array}{l}\text { Moisture } \\
(\%)\end{array}$ & $\begin{array}{l}\text { Ash } \\
(\%)\end{array}$ & $\begin{array}{l}\text { Fat } \\
(\%)\end{array}$ & $\begin{array}{l}\text { Protein } \\
(\%)\end{array}$ & $\begin{array}{l}\text { Carbohydrate } \\
(\%)\end{array}$ & $\begin{array}{l}\text { Crude Fiber } \\
(\%)\end{array}$ \\
\hline $\begin{array}{l}A=100 \% \mathrm{WF} \\
\text { Control }\end{array}$ & $3.00^{\mathrm{e}}$ & $1.05^{\mathrm{c}}$ & $21.93^{\mathrm{e}}$ & $7.08^{\mathrm{a}}$ & $65.24^{\mathrm{a}}$ & $1.70^{\mathrm{b}}$ \\
\hline $\begin{array}{l}B=80 \%: 10 \%: 10 \% \\
\text { WF }: \text { SF }: \text { BF }\end{array}$ & $8.04^{\mathrm{a}}$ & $1.45^{\mathrm{b}}$ & $27.66^{\mathrm{a}}$ & $6.48^{\mathrm{b}}$ & $54.48^{\mathrm{e}}$ & $1.89^{\mathrm{a}}$ \\
\hline $\begin{array}{l}C=70 \%: 15 \%: 15 \% \\
\text { WF : SF : BF }\end{array}$ & $4.2^{\mathrm{d}}$ & $1.30^{\mathrm{b}}$ & $25.01^{\mathrm{d}}$ & $5.94^{\mathrm{c}}$ & $62.55^{\mathrm{b}}$ & $1.00^{\mathrm{d}}$ \\
\hline $\begin{array}{l}D=60 \%: 20 \%: 20 \% \\
\text { WF }: S F: B F\end{array}$ & $5.68^{\mathrm{c}}$ & $1.79^{\mathrm{a}}$ & $25.56^{\mathrm{b}}$ & $4.98^{\mathrm{e}}$ & $59.79^{c}$ & $2.20^{\mathrm{a}}$ \\
\hline $\begin{array}{l}E=60 \%: 25 \%: 25 \% \\
W F: S F: B F\end{array}$ & $6.79^{b}$ & $1.17^{\mathrm{c}}$ & $27.37^{\mathrm{c}}$ & $5.59^{d}$ & $57.68^{d}$ & $1.40^{\mathrm{c}}$ \\
\hline
\end{tabular}

Means with different superscript in the same column are significantly different from each other ( $\mathrm{p} \square 0.05$ )

$\mathrm{WF}=$ Wheat Flour

$\mathrm{BF}=$ Breadfruit Flour

$\mathrm{SF}=$ Sweet Potato Flour

Table 3: Proximate Composition of African breadfruit and Sweet potato-wheat cake.

\begin{tabular}{|c|c|c|c|c|c|c|}
\hline Samples & $\begin{array}{l}\text { Moisture } \\
(\%)\end{array}$ & $\begin{array}{l}\text { Ash } \\
(\%)\end{array}$ & $\begin{array}{l}\text { Fat } \\
(\%)\end{array}$ & $\begin{array}{l}\text { Protein } \\
(\%)\end{array}$ & $\begin{array}{l}\text { Carbohydrate } \\
\text { (\%) }\end{array}$ & $\begin{array}{l}\text { Crude Fiber } \\
(\%)\end{array}$ \\
\hline $\begin{array}{l}\mathrm{A}=100 \% \mathrm{WF} \\
\text { Control }\end{array}$ & $21.97^{\mathrm{e}}$ & $2.25^{\mathrm{a}}$ & $18.93^{\mathrm{d}}$ & $7.34^{\mathrm{a}}$ & $47.76^{\mathrm{d}}$ & $0.75^{\mathrm{c}}$ \\
\hline $\begin{array}{l}B=80 \%: 10 \%: 10 \% \\
W F: S F: B F\end{array}$ & $28.47^{\mathrm{a}}$ & 1.67 & $18.35^{\mathrm{e}}$ & $5.68^{\mathrm{d}}$ & $44.82^{\mathrm{e}}$ & $1.01^{\mathrm{b}}$ \\
\hline $\begin{array}{l}C=70 \%: 15 \%: 15 \% \\
W F: S F: B F\end{array}$ & $23.12^{\mathrm{b}}$ & $2.19^{\mathrm{a}}$ & $19.58^{c}$ & $5.78^{\mathrm{c}}$ & $48.24^{\mathrm{b}}$ & $1.09^{\mathrm{b}}$ \\
\hline $\begin{array}{l}D=60 \%: 20 \%: 20 \% \\
W F: S F: B F\end{array}$ & $20.23^{\mathrm{d}}$ & $2.03^{\mathrm{c}}$ & $21.79^{\mathrm{a}}$ & $5.94^{\mathrm{b}}$ & $48.18^{\mathrm{c}}$ & $1.82^{\mathrm{a}}$ \\
\hline $\begin{array}{l}E=50 \%: 25 \%: 25 \% \\
W F: S F: B F\end{array}$ & $22.26^{\mathrm{c}}$ & $2.12^{b}$ & $20.44^{\mathrm{b}}$ & $5.78^{c}$ & $48.72^{\mathrm{a}}$ & $0.68^{\mathrm{c}}$ \\
\hline
\end{tabular}

Means with different superscript in the same column are significantly different from each other $(\mathrm{p} \square 0.05)$.

$\mathrm{WF}=$ Wheat Flour

$\mathrm{BF}=$ Breadfruit Flour

$\mathrm{SF}=$ Sweet Potato Flour 
Table 4: Mean Sensory Score Of biscuits Produced from African breadfruit and Sweet Potato- wheat Blends

\begin{tabular}{|c|c|c|c|c|c|}
\hline SAMPLES & $\begin{array}{l}\text { Color/ } \\
\text { appearance }\end{array}$ & Aroma & Taste & Texture & General acceptability \\
\hline $\begin{array}{l}\mathrm{A}=100 \% \mathrm{WF} \\
\text { Control }\end{array}$ & $6.3^{b}$ & 6.1 & 6.4 & 6.4 & $6.4^{\mathrm{a}}$ \\
\hline $\begin{array}{l}B=80 \%: 10 \%: 10 \% \\
W F: S F: B F\end{array}$ & $7.05^{\mathrm{a}}$ & 6.6 & 6.4 & 6.1 & $5.9^{b}$ \\
\hline $\begin{array}{l}C=70 \%: 15 \%: 15 \% \\
\text { WF : SF : BF }\end{array}$ & $7.1^{\mathrm{a}}$ & 6.1 & 6.4 & 6.7 & $7.1^{\mathrm{a}}$ \\
\hline $\begin{array}{l}D=60 \%: 20 \%: 20 \% \\
\text { WF: SF : BF }\end{array}$ & $6.9^{\mathrm{a}}$ & 5.9 & 6.3 & 6.1 & $6.3^{\mathrm{a}}$ \\
\hline $\begin{array}{l}\mathrm{E}=50 \%: 25 \%: 25 \% \\
\mathrm{WF}: \mathrm{SF}: \mathrm{BF}\end{array}$ & $7.5^{\mathrm{a}}$ & 6.5 & 6.9 & 6.4 & $7.0^{\mathrm{a}}$ \\
\hline
\end{tabular}

Means with different superscript in the same column are significantly different from each other ( $\mathrm{p} \square 0.05)$.

$\mathrm{WF}=$ Wheat Flour

$\mathrm{BF}=$ Breadfruit Flour

$\mathrm{SF}=$ Sweet Potato Flour

Table 5: Mean Sensory score of Cakes Produced From Wheat/African breadfruit \& Sweet Potato Blends

\begin{tabular}{|c|c|c|c|c|c|}
\hline SAMPLES & Color/appearance & Aroma & Taste & Texture & General acceptability \\
\hline $\begin{array}{l}A=100 \% \mathrm{WF} \\
\text { Control }\end{array}$ & 7.40 & $7.25^{\mathrm{a}}$ & $7.20^{\mathrm{a}}$ & $7.55^{\mathrm{a}}$ & $6.75^{\mathrm{b}}$ \\
\hline $\begin{array}{l}B=80 \%: 10 \%: 10 \% \\
\text { WF : SF : BF }\end{array}$ & 7.50 & $8.05^{\mathrm{a}}$ & $8.00^{\mathrm{a}}$ & $7.85^{\mathrm{a}}$ & $8.05^{\mathrm{a}}$ \\
\hline $\begin{array}{l}C=70 \%: 15 \%: 15 \% \\
\text { WF : SF : BF }\end{array}$ & 7.15 & $7.30^{\mathrm{a}}$ & $7.25^{\mathrm{a}}$ & $7.25^{\mathrm{a}}$ & $6.75^{\mathrm{b}}$ \\
\hline $\begin{array}{l}D=60 \%: 20 \%: 20 \% \\
\text { WF: SF : BF }\end{array}$ & 6.75 & $6.90^{\mathrm{b}}$ & $6.65^{\mathrm{b}}$ & $7.00^{\mathrm{b}}$ & $6.45^{\mathrm{c}}$ \\
\hline $\begin{array}{l}E=50 \%: 25 \%: 25 \% \\
W F: S F: B F\end{array}$ & 6.20 & $6.65^{\mathrm{b}}$ & $6.30^{\mathrm{b}}$ & $6.35^{\mathrm{b}}$ & $6.05^{\mathrm{c}}$ \\
\hline
\end{tabular}

Means in the same column and followed by the same letters are not significantly different from each other (P $\square 0.05$ ).

$\mathrm{WF}=$ Wheat Flour

$\mathrm{BF}=$ Breadfruit Flour

$\mathrm{SF}=$ Sweet Potato Flour

\section{Discussions}

The proximate composition of the various flour blends are shown in Table 2 and 3. The moisture content ranged from $3.00 \%-6.79 \%$ in biscuit and $21.97 \%-22.26 \%$ in cake showing an increase with substitution of African breadfruit and sweet potato flour. The results show that the blend wheat/ sweet potato/African breadfruit flour; 60:20:20, had the lowest protein in cake while sample with 80:10:10 had the highest lowest protein content for biscuits. while $100 \%$ wheat sample had the highest in both cases. Fat content increased with an increase in substitution of African breadfruit and sweet potato flour with the sample 80:10:10 been highest for cake and sample 60:20:20 highest for biscuit. Fiber contents were higher in sample D of both biscuits $(2.20 \%)$ and cake $(1.82 \%)$, showing an increase with substitution, while carbohydrate decreased with increase in substitution in biscuit (table 3) and increased with substitution in cake (table 4). Proximate analysis results for biscuits and cake showed a significant difference $(p<0.05)$ in all its parameters

Result of sensory evaluation of African breadfruit and wheat-sweet potato biscuit samples showed significant difference $(\mathrm{P} \leq 0.05)$ with increased level of substitution. For substitution levels of $20 \%$ breadfruit-sweet potato flour, attribute like aroma, taste, texture and general acceptability showed no significant difference $(\mathrm{P} \geq 0.05)$ and in other levels in cake and biscuit. There were no significant differences $(\mathrm{P} \geq 0.05)$ in color of both biscuit and cake samples. Substitution levels of up to $20 \%$ were generally acceptable in cake and $30 \%$ in biscuit samples. The level of ingredients of cake and biscuit recipes preparation have been reported to affect the sensory attributes, consumer's preference and overall acceptability of the cakes (Petrukhing et al.,2004) and biscuit.

The study have shown that African breadfruit/sweet potato-wheat composite flour has the potential to produce biscuit and cake of acceptable quality without altering the 
sensory properties of the final products. Flour substitution of breadfruit-sweet potato up to levels of $20 \%$ in cake and $30 \%$ in biscuits were generally accepted. Consumption of cake and biscuit samples supplemented with African breadfruit flour and sweet potato flour could be said to be beneficial in terms of improving the nutritional value of the product since biscuit and cake consumption is $\mathrm{n}$ the increase as a convenient food for ladies and children in this part of Nigeria.

\section{References}

[1] AOAC (1990).Association of Official Analysis Chemist. $15^{\text {th }}$ Edition, Washington, DC

[2] Baiyeri, K.P. and Mbah, B.N. (2006): Effects of soiless and soil-based Nursery media on seedling Emergency, Growth and Response to Water stress of African breadfruit (Treculia Africana Decne).African Journal Biotechnology 5(15): 1400-1405.

[3] Baking and Baking Science: Part Ten - Cake Ingredient functions, formula Balancing, mixing procedures and small quantity baking caked formulars (2012). www.bakingandbakingscience.com/jprejean@att.net

[4] Collins, M. (1989): Economic Analysis of wholesale demand for sweet potatoes In Lima, Peru, M.sc. Thesis, Department of Agricultural and Resource Economics, University of Florida, Gainesville, USA. Pp. 1-164.

[5] Eke- Ejiofor, J. and Kiin-Kabari D (2010): Chemical, pasting, functional and sensory properties of Sweet and Irish Potato Chips. Nigeria Food Journal 28 (2), 47-48.

[6] Eke, J., Achinewhu, S.C. and Sanni, L. B (2004): Nutritional and sensory Qualities of some Nigerian cakes. Nigeria Food Journal 26 (2), 12-17.

[7] Enibe, D.O. (2007): Treculia africana consumer Acceptability and utilization For food security and industrial Development. In: Olufajo, O.O., Omokere, D.F., Akpa, G.N and Sanni, S.A. (eds.). Proceeding of the $41^{\text {st }}$ Annual Conference of the Agricultural Society of Nigeria (ASN) Held at ABU, Zaria between $22^{\text {nd }}$ and $26^{\text {th }}$ of October, pp. $455-458$.
[8] Giami S.Y. Amasisi T., Ekiyor T. (2004): Comparison of bread making Properties of composite flour from kernels of roasted and boiled African breadfruit (Treculiaafricanadecne) seeds. J. Material Res. 1(1): 16-25.

[9] Ihekoronye, A.I and Ngoddy, P.O. (1985): Integrated food science and Technology for the tropics. Macmillan Education Ltd., ISBN 0-333-38883-6.

[10] Kure, O.A, Bahago EJ., Daniel, E.A (1998): Studies on the proximate Composition and effect of flour particle size on Acceptability of Biscuit Produced from blends of soybeans and plantain flours. Afri. J. Food Nutrition Devt. 7(1):1-22.

[11] Kulkarni, S.D (1997): Roasted soybean in cookies: Influence on product Quality. J. Food Sci. Technol. 34:503505 .

[12] Keay, R.W.J. (1989): Trees of Nigeria: A Revised Version of Nigeria Trees. Vol. 1 and 2. Stanfield DP, Clarendon Press, Oxford.

[13] Morton, S.(1988): Bread without wheat. J. New Sci. 28 April. Pub. National Academy of Sci. Tropical Legumes: Resources for the future

[14] Okafor, J.C. (1985): Selection and Improvement of Indigenous Tropical fruit Trees: problems and prospects. Journ.For Res. Vol. 1, No. 2:87-95.

[15] Okafor, J.C. and Okolo, H.C. (1974): Potentials and some indigenous fruit Trees of Nigeria. Paper presented to the $5^{\text {th }}$ Annual conference of the Forestry Association of Nigeria, Jos.

[16] Satin, M., (1988): Bread without wheat. J. New Sci. 28 April. Pub. National Academy of Sci. Tropical Legumes: Resources for the future.

[17] Ulm, S.G. (1988): The effect of storage conditions on selected Quality Attributes of sweet potato flour, Thesis of the University of Tennessee, Knoxville. P. 7-26.

[18] Woolfe, J.A. 1992. Sweet potato: An untapped food Resource. Cambridge University press, Cambridge, England.

[19] Wade P. (1988). Biscuits, cookies and crackers: the principles of craft. 1:1-4

[20] World Agroforestry Centre (WAC, 2004).Treculiaafricana. 